sequenco, although their success in this aspect is rather limited, because no indications of cultivated plants were found in any of the pollen profiles taken from three different areas. Of some interest is the tentative recognition of three episodes within late glacial times, representing the pre-Valders ice retreat, Two Creeks interstadial and Valders ice advance, although until now it was bolieved that the Valders re-advance in fact covered the area. The detailed geological evidence for this is not discussed, but clearly some further consideration is required to resolve the problem. The subsequent postglacial vegetational history is well documented, and radiocarbon dates from the area and elsewhere combine to present a closely detailed picture of the environmental conditions which influenced the prehistoric Indian groups attested here from about 3000 B.c.

\section{Traditional Celtic Customs}

THE latest issue of Folk Life $(3 ; 1965)$, the journal of the Society for Folk Life Studies, contains a number of papers recording traditional eustoms and technological processes of certain areas within the British Isles. It is noteworthy that almost all the areas selected for study are in the 'Highland Zone', the Celtic fringe of north. western Europe. A well-illustrated article on "Pennine Houses" records a number of constructional features ranging from cruck-framed houses and fourteenthcentury aisled halls to stone buildings of the eighteenth century. There follow papers dealing with Cornish migrants to America, customs and traditions in Glamorgan and Ulster, and elver fishing on the Severn. Of particular interest is the publication of a plan, with descriptive text, of the multiple-tenancy farm at Auchindrain in mid-Argyll. The fine preservation of this complex is due to a continuity of occupation down to relatively recent years, and the linear settlement, of mainly cruck-framed buildings, is expected to be maintained in its present or restored state. Of more widespread interest may be the paper on holed stone amulets and their traditional use as protective or recuperative agencies against such misfortunes as nightmare, bewitching and disease of horses and cattle, rheumatism, and night-riding. The volume also contains a number of notes and reviews.

\section{Commentariolus of Copernicus}

Dr. J. Dobrzyeki (Institute for the History of Science, Polish Academy of Science, Warsaw) and Dr. W. P. D. Wightman (Department of History and Philosophy of Science, King's College, Aberdeen) have written to the Editor as follows: "It is fairly generally known that early in his life, and some considerable time before the publication of his epoch-making De Revolutionibus, Copernicus circulated a few MS. copies of a brief work (commonly reforred to as the Commentariolus) in which the idea of a heliocentric system was sketched out. Before the end of the sixteenth century Tycho Brahe had difficulty in obtaining a copy; thereafter it disappeared until the nineteenth century when two copies-an apparently complete one in Stockholm, and a somewhat defective one in Vienna-were brought to light. A few years ago a single page of the Commentariolus was discovered in the interleaved copy of the Basle (1566) edition of the De Revolu. tionibus in the hand of Dr. Duncan Liddel (whose library passed to the Marischal College and University of Aberdeen on his death in 1613) (Science and the Renaissance, 2, item No. 172; Edinburgh, 1962). A further search rocently gave promise of a complete transcript of the Commentariolus on inserted folios widely scattered throughout the book. As a result of a more detailed collation we are now convinced that these MS. pages comprise a complete transcript corresponding closely to, but differing in some significant features from, the Stockholm MS. of the Commentariolus. A new recension of the Commentariolus based on all extant transcripts will be prepared in the Institute for the History of Science
(Polish Academy of Science) in Warsaw with the view of publication, probably in the course of 1966 ".

\section{Albert Lasker Medical Research Awards}

THE twentieth annual Albert Lasker Medical Research Awards have been presented to Prof. A. B. Sabin, professor of research pediatrics at the University of Cincinnati College of Medicine, in recognition of his fundamental contribution to the understanding of the nature of poliomyelitis, and the development of a live vaccine that can be taken by mouth, and to Prof. R. W. Holley, professor of bioichemistry at Cornell University, in recognition of his determinetion of the ehemical structure of alanine $t$ RNA.

\section{Feldberg Foundation Award}

THE British prizewinner for 1965 of the Feldberg Foundation Award is Prof. B. Katz, of the Department of Biophysics, University College, London, and the German prizewinner is Dr. G. Braunitzer of the MaxPlanck-Institut für Biochemie, Munich. The Feldberg Foundation for German-English scientific exchange was established in 1961 through the generosity of Prof. W. Feldberg, a member of the staff of the Medical Research Council at the National Institute for Medical Research, London. The Foundation provides for a prize to be awarded each year to one German and one British scientist. In recognition of the gift the German recipient gives a lecture in Britain and the British prizewinner lectures in Germany.

\section{Davisson-Germer Prize}

The American Physical Society and Bell Telephone Laboratories have announced the establishment of a new Prize for outstanding contributions in the fields of electron and atomic physics. The award will be given in honour of the late C. J. Davisson and of L. H. Germer, former members of the research staff of the Bell Laboratories, and pioneers in the study of the wave-like quality of electrons. The award will be presented every other year by the American Physical Socicty until 1973, and will consist of a 2,500 dollar cash prize and a citation describing the accomplishments of the recipient.

\section{New Shell Research Fellowship}

A NEw series of post-doctoral research fellowships, each worth $£ 1,300$ per annum, has been instituted by Shell International Petroleum Co. in extension of the considerable support it already gives to research and education. This is announced in the November issue of Shell's Science and Technology Newsletter. These awards, tenable for 2 or 3 years in any university, college of tochnology or other recognized research establishment in Britain, are intended to assist Fellows to pursue research or a subject. of their own choice lying within the spheres of engineering, mathematics, physics, chemistry, biochemistry, botany, zoology or microbiology-disciplines with which Shell's own research in the United Kingdom is concerned. Two awards will be made each year. Candidates may bo of any nationality but must hold a Ph.D. degree or equivalent, and be less than thirty years old on ()ctober 1 of the year of appointment. Application forms for the 1966-67 research fellowships ean be obtained from the Secretary, Shell Grants Committee, Shell Centre, London, S.E.1, and should be returned by February 1, 1966.

\section{South-East Asia Treaty Organization: Research Fellow- ships}

The British Council, on behalf of the South-East Asia, Treaty Organization (SEATO), announces that SEATO research fellowships for 1966-67 are available to scholars whose academic standards are of approximately doctorate level. The research projects for which the SEATO grants will be given should relate to social, economic, political, 